\title{
Occupational hazards in printing industry
}

\author{
J. S. Kiurski ${ }^{1}$ B. B. Marić $^{1}$ - S. M. Aksentijević ${ }^{2}$ I. B. Oros ${ }^{1}$ V. S. Kecić ${ }^{1}$
}

Received: 27 July 2015/Revised: 9 December 2015/Accepted: 11 January 2016/Published online: 25 January 2016

(C) Islamic Azad University (IAU) 2016

\begin{abstract}
This paper, through certain printing techniques, examines the types of occupational pollutants and the adverse impacts of the printing process. Also, it proposes the measures for better preservation and environmental protection. The paper analyzes the results of the quantitative identification of hazardous materials from various printing techniques: pad, screen, offset, flexographic, and digital. The study included the analysis of waste printing inks and purification of printing wastewater with adsorption methods. Besides that, the preliminary monitoring of ambient indoor air quality was performed. The multiple regression analysis was applied on the obtained experimental results, in order to determine the mutual correlation between the ozone and the total volatile organic compounds and microclimate parameters. It was observed that a quantitative correlation exists between the investigated occupational hazards, which also indicate the strength of the agreement. The obtained results could be useful to evaluate the tendency of hazardous air pollutants in printing industries worldwide.
\end{abstract}

Keywords Printing process - Hazardous material · Sustainable development · Indoor pollutant - Statistical analysis

J. S. Kiurski

kiurski@uns.ac.rs

1 Faculty of Technical Sciences, University of Novi Sad, Trg Dositeja Obradovića 6, Novi Sad 21000, Serbia

2 Business Technical College, Trg Svetog Save 34, Užice 31000, Serbia

\section{Introduction}

In the late eighties, human society evolved from basic concepts of social reproduction to the concept of sustainable development, which generally implies changes in the structure, functions and activities of the system. Sustainable development is often related to the environment and involves changes in society concerning the available resources, endangering natural systems and providing the long-term survival of the same. It is possible to investigate, analyze and draw conclusions to ensure sustainable development, as well as to optimize its components (Wallis et al. 2011; Bilen et al. 2008; Bao and Fang 2013; Yigitcanlar and Kamruzzaman 2014; Yigitcanlar and Teriman 2015).

It is an undisputed fact that the environment is polluted every day with a large number of systems and, their components, and by individuals. The biggest polluters are the various parts of industry, in which an important role belongs to the printing industry (Mollah et al. 2000; Huang and Shih 2008). The printing industry may directly pollute the soil and natural water through wastewater systems, threatening the existence of plant and animal life. Additionally, indirectly, through meteorological conditions and acid rain, it may endanger the living environment. (Kiurski et al. 2012b). Beside that, our recent studies showed that microclimate parameters, temperature, relative humidity and light intensity, have influence on emission of various organic hazards in printing indoor environments that potentially affect the worker's health (Kiurski et al. 2013a, b). Namely, it is known that light intensity leads to the increase in the overall temperature in printing indoor environments. It occurs as a result of productivity increasing due to increased speed of production lines, which causes an increase in heat and dissipation of energy 
from the UV lamps and the appearance of large amounts of ozone in indoor environment. Ozone is very reactive gas, and it reacts with other pollutants in the indoor air by creating a new compound. These facts have contributed to repeat the measurement of microclimate parameters such significant impacts to the pollutant emission into the printing indoor environment.

Because of these facts, it is interesting and useful to investigate and monitor the processes within the printing industry, as well as the parameters of pollutants, to provide better management of environmental protection and sustainable development. The objective of this study was to examine the presence of certain pollutants through various printing techniques in the printing facilities on the territory of Novi Sad, Serbia, during the period December 2011May 2012 and, to note their negative impact on the indoor environment, as well as the mutual correlation between the target pollutants and the microclimate parameters. This study was performed in the printing industry in Novi Sad, covering a variety of printing techniques: pad, screen, webfed offset, flexography and digital printing. The results are represented in terms of the quantity of the pollutants, and the correlation of the examined phenomena through statistical analysis.

\section{Environmental pollutants and waste}

The environment includes a large number of processes and components: the atmosphere, hydrosphere, lithosphere, and biosphere, as well as their interactions. Population growth, urban development, the increase in economic activity and the application of chemicals in industry lead to excessive release of pollutants into the environment and the resulting threats (Kiurski 2010). Evaluating the ecological effects of environmental contamination goes beyond observing the co-occurrence of contaminants and adverse effects to documenting the cause and effect relationships. For most contaminants and metals, there is currently little information regarding their potential toxicological significance in ecosystems, particularly the effects of long-term, low-level environmental exposures to emerging pollutants (Hoenicke et al. 2007; Aina et al. 2009; Vojinovic-Miloradov and Kiurski 2010; Panwar et al. 2011; Wang et al. 2013; Dursun et al. 2015).

Although great advances have been made in the detection and analysis of trace pollutants, during recent decades, a wide array of undetected contaminants of emerging environmental concern still need to be identified and quantified in various environmental components (Nwachukwu et al. 2010). Pollutants may be migrated and persistent in air, water, soil, sediments and ecological receptors, even at low concentrations. Because of their particular characteristics, pollutants require changes in the conventional approach to pollution prevention and control, although they result from similar domestic, commercial and industrial activities, as conventional contaminants (Deblonde et al. 2011; Gavrilescu et al. 2015).

Thus, waste includes all materials that are created during production processes that have no intended use. Waste can be classified as municipal waste, industrial waste, hazardous waste, mining waste, biodegradable municipal waste and agricultural waste. The main purpose of waste management technologies and policies is to protect human and environmental health by reducing the negative impacts of waste and finding beneficial uses for it. Waste management technologies can reduce the harmful impacts of waste, particularly those relating to energy consumption and climate change. Performance indicators are often used to assess the quality of waste on the environment, as well as a comparison of the ranking assessment of the impact on the environment (Misra and Pandey 2005; Musee et al. 2008; Zaman 2013; Al-Salem et al. 2014; Greene and Tonjes 2014; Yigitcanlar and Kamruzzaman 2014; Yigitcanlar and Teriman 2015).

\section{Printing industry as a polluter}

Small printing facilities present diffuse and permanent polluters. Each printing technique (pad, screen, offset, flexography, digital) is unique in own way, with certain characteristics of waste flows. As a daily companion to human activity, the printing industry generates wastes classified roughly as solid, liquid and gaseous wastes. Solid waste contains canisters, used film packages, damaged plates, developed film, outdated materials, test production, bad printing (or spoilage) and paper waste. Liquid waste includes a variety of inks, solvents, acids, resins, lacquers, dyes, driers, extenders, modifiers, varnishes, and other solutions. Waste printing inks are the highest sources of organic and inorganic water pollution (Kiurski et al. 2012c).

Printing wastewater contains different types of hazardous and harmful substances depending on the raw materials used during the printing production. Zinc ions are harmful to humans and other biological systems, and they are particularly common in printing wastewater (Kiurski et al. 2009; Noonpui et al. 2010). The most common form of waste gas emissions are various gases and volatile organic compounds (VOC) arising from process chemicals and cleaning solutions (Guo et al. 2004; Caselli et al. 2009; Andrade et al. 2012).

\section{Pad printing}

Pad printing is an indirect offset (or gravure) printing process in which an image is transferred over the silicone pad to the surface to be printed (E3 Systems Ltd. 2015). 
The most common emissions produced by the pad printing process are gases and VOCs from process chemicals and cleaning solutions. Cleaning products, such as washes for silicone pads, ink containers and presses, have traditionally been petroleum-based products containing naphtha, mineral spirits, methanol and toluene. Volatile organic compounds possess high activity in the atmosphere where, together with the high concentration of oxygen, $\mathrm{OH}$ radicals, and UV radiation, they participate in a series of complex photochemical reactions that lead to smog. These reactions occur in the presence of nitrogen oxide $\left(\mathrm{NO}_{\mathrm{x}}\right)$ to form secondary contaminants, such as ozone, aldehydes, nitrates, and so on. A large group of persistent organic compounds, such as xylenes, ketones, alcohols and aliphatic compounds can reach the stratosphere and react with ozone, producing ozone holes, thus exposing the terrestrial surface to the malignant effects of UV radiation. In addition, many VOCs, present in higher concentrations in indoor environments, are considered to be toxins, carcinogens, or mutagens or to be responsible for allergic symptoms, such as asthma or eczema. Their adverse effect on air quality and human health are cause for very careful control (An et al. 2014; Ji et al. 2008; Kumagai et al. 2013; Su et al. 2013; Dhada et al. 2015; Kommalapati et al. 2015; Venkanna et al. 2015).

\section{Screen printing}

Screen printing as a technique uses a woven mesh to support an ink-blocking stencil. The attached stencil is forming open areas of mesh that transfer ink as a sharpedged image onto the substrate (PNEAC 1995).

A wide range of ink formulations used in screen-printing processes are available, depending on the substrate and the requirements for the printed product. The screen-printing industry uses liquid materials (organic solvents, inks, varnishes, and cleaning agents) that generate numerous toxic, hazardous substances of organic origin, especially contaminants from the group of VOCs (Kiurski et al. 2013c). Isophorone is the most widely used screen-printing ink solvent (comprising $75 \%$ of the total solvent), followed by cyclohexanone, petroleum distillates, butyl acetate, diacetone alcohol, 2-ethoxy ethyl acetate and xylene. These substances are pollutants in screen printing wastewater and increase the chemical oxygen demand (COD) and biological oxygen demand (BOD) values. A particularly environmentally unfavorable situation is the use of oxidants that can react with other components and thereby provide an organic halide adsorbent in a concentration of $6 \mathrm{mg} / \mathrm{L}$. Screen press operators are exposed to organic vapors during ink mixing, printing, screen washing and drying of final products. The major exposure determinant is the proximity of the solvent evaporating surfaces to the workers' breathing zone (Kamyshny et al. 2011).

\section{Offset printing}

Offset printing is the most widespread printing process, which relies on the fact that water and oil do not mix and that the printing and non-printing elements are in the same plane. During the printing process, a fountain solution wets the non-image areas on the printing plate, and the printing ink adheres to the image areas (EPA 2015).

Pollutants emitted during the offset printing process primarily originate from used raw materials.

Offset printing ink is a very viscous mixture that consists of pigment, binder resin and additives.

The fountain solution usually contains plate preservative agents, wetting agents, isopropyl alcohol (IPA), buffer substances and anti-microbial additives. Because of its flammability, volatility and toxicity, the usage of IPA has been of considerable concern. IPA added to the fountain solution evaporates into the ambient air and contributes to the release of pollutants from the group of volatile organic compounds (Svendsen and Rognes 2010; Kiurski et al. 2013a). Further, VOCs can contribute to the formation of new oxidation products and secondary aerosols that can cause sensory irritation symptoms (Dhada et al. 2015).

Odorous emissions are released during the heating and cooling of the varnish.

Aluminum printing plates are widely used in offset printing, and therefore, aluminum is the most common pollutant. Its presence may cause an increase in $\mathrm{pH}$ values of wastewater. However, a larger problem may occur after discharges of spent photochemical baths during the manual platemaking (Kiurski 2010).

\section{Flexographic printing}

Flexographic printing is a common printing method in the packaging field. The printing method is characterized primarily on the flexible rubber relief printing plate and the low viscosity inks that make it suitable for use on almost any substrate, and the formulation of the inks depends on the process and printed matter. Generally, the solventbased and water-borne inks are dried by the solvent evaporation, or they are absorbed in the substrate. The basic elements in flexographic inks are colorants, binders and solvents (Johnson 2008).

Three basic types of materials used in flexographic printing plate production are rubber plates, liquid photopolymer media and solid-sheet photopolymers. The major components in the photosensitive layer are binders, monomers and photo-initiators.

The washout solvents are frequently chlorinated solvents, such as perchloroethylene (Andrade et al. 2012). Because of the environmental hazards of chlorinated solvents, substitutes are being sought. A negative feature of 
the rinse solution is its organic origin, and, if it reaches the aquifer, it will consume oxygen and make it scarce. Additionally, it increases the COD and BOD values of wastewaters (Kiurski 2010).

\section{Digital printing}

Digital printing refers to methods of printing from a digitalbased image directly to a variety of media. The application of digital printing has increased recently, because this technique offers a variety of benefits, such as speed, flexibility, cleanliness, competitiveness and eco-friendliness (Zori and Soleimani-Gorgani 2012). Inks for digital printing are usually classified into two categories, dye and pigment inks. Pigmented inks dry more slowly than dyes, but they are more suitable for printing on matt or plain paper surfaces, producing sharper details and deeper colors (Zhang et al. 2012).

Water-based inks contain 30-80\% water. From the standpoint of environmental protection, given that the water content is up to $80 \%$, the harmful indoor emissions are minimal. The waste ink cannot be discharged directly into the recipient due to the presence of dyes and other ingredients. Thus, ink manufacturers recommend disposing of their water-based inks as a hazardous waste (Karanikas et al. 2013).

\section{Printing inks}

Inks are the most important materials of the printing process. Most of the pigments were obtained from metals before the 1970s. These metals are often present in amounts above the allowed limit and the prescribed standards, thus inks present hazardous waste. Today, ink manufacturers have developed alternative organic substitutes that are not as dangerous as inorganic precursors. Some states have different laws regarding the disposal of waste ink (Kamyshny et al. 2011; Ning et al. 2014).

Printing inks are principally made up of colorants (pigments, dyes), vehicles (binders), additives and carrier substances (solvents). Depending on the type of printing process, inks have variable flow properties, which range from extremely thin (watery), through highly viscous, to dry (powder-like). Compositions of printing inks for various printing techniques and quantities of pollutants are given in Table 1 (Kiurski 2010; Maji and Bhaskarwar 2003).

\section{Washout solvents}

The cleaning and maintenance of printing machines are important for quality printing production, but the health risks of employees must not be forgotten. Most cleaning solutions are obtained from petroleum, a highly volatile and flammable substance. These substances represent health and safety risks in the working environment (flammability class of type A I, A II and A III; Table 2) (Kiurski 2010). In the atmosphere, they participate in chemical reactions producing the group of photo-oxidants and lead to the smog formation.

However, the observed properties are not in accordance with good technological conditions (Bernd Schwegmann GmbH \& Co 2015). Conventional detergents are mixtures of hydrocarbons with an ignition temperature of $55^{\circ} \mathrm{C}$. This is the lowest temperature at which the steam is developed to such an extent that a spark can be created above the liquid, yielding a combustible mixture.

\section{Materials and methods}

\section{Identification of hazards and microclimate parameters}

For the quantitative determination of pollutants, the following methods and instruments were used (Kiurski et al. 2012b):

- Gas chromatography, using a Voyager (Perkin Elmer Photovac Inc., USA) mobile gas chromatograph, to determine the total volatile organic compounds (TVOCs) concentration. The basic principle of mobile gas chromatograph is to provide flexibility of analysis and reliable results. It features a built-in analysis engine with three-column configuration, an isothermal oven for fast GC analysis, and a miniaturized PID/ECD dualdetection system (Photovac Inc 2002).

- A portable ozonometer, a Aeroqual Series 200 (Aeroqual Ltd., New Zealand), to determine the ozone concentration (Kiurski et al. 2013c). Aeroqual's unique system of interchangeable sensor heads means one monitor can measure many gases, and servicing is as simple as swapping one sensor head for another. Unique ozone sensor technology use Aeroqual's proprietary gas sensitive semiconductor (GSS) sensors which incorporate a dynamic baseline adjustment to reduce sensor drift. These sensors provide analyzer-like performance, with $1 \mathrm{ppb}$ detection limits (Aeroqual Ltd 2014).

- Inductively coupled plasma mass spectrometry (ICPMS), using a Perkin Elmer Elan 5000 mass spectrometer (Perkin Elmer Inc., USA), to determine the trace metals in waste printing inks and fresh and waste printing developer. Inductively coupled plasma mass spectrometry is an analytical technique used for elemental determinations. The ICP source converts the atoms of the elements in the sample to ions. These 
Table 1 Ink's typical pollutants for specific printing techniques (Kiurski 2010)

\begin{tabular}{|c|c|c|c|c|c|}
\hline Printing techniques & Graphic materials & Pollutants & $\operatorname{STEL}^{\mathrm{a}}(\mathrm{ppm})$ & Toxic effects & Danger classification \\
\hline Offset printing & Solvent-based inks & Hydrocarbons & - & 1 & AIII \\
\hline \multirow[t]{7}{*}{ Flexographic printing } & \multirow[t]{7}{*}{ Solvent-based inks } & Ethanol & 1000 & 0 & $\mathrm{~B}$ \\
\hline & & Ethoxypropanol & - & 1 & B \\
\hline & & Methoxypropanol & 100 & 1 & $\mathrm{~B}$ \\
\hline & & Ethyl acetate & 200 & 1 & AI \\
\hline & & Methyl ethyl ketone & 200 & 1 & AI \\
\hline & & Methoxypropyl acetate & 50 & 1 & AII \\
\hline & & Isopropyl acetate & 200 & - & AI \\
\hline \multirow[t]{10}{*}{ Pad printing } & \multirow[t]{10}{*}{ Solvent-based inks } & Naphtha & - & 2 & AII \\
\hline & & 2-methoxy-1-1-methylethyl & 90 & 1 & $\mathrm{~B}$ \\
\hline & & Acetate & - & 1 & AII \\
\hline & & Butyl glycol acetate & 50 & 1 & $\mathrm{~B}$ \\
\hline & & 4-hydroxy-4-methylpentan-2-one & 125 & 2 & AII \\
\hline & & Ethylbenzene & 20 & 1 & - \\
\hline & & Isotridecanol & 50 & 1 & - \\
\hline & & Cyclohexanone & 100 & 2 & AII \\
\hline & & Butyl glycol & 950 & 1 & AII \\
\hline & & Xylenes & 100 & 2 & AIII \\
\hline \multirow[t]{6}{*}{ Screen printing } & \multirow[t]{6}{*}{ Solvent-based inks } & Acetate & 950 & 1 & AII \\
\hline & & Glycolic acid butyl ester & 50 & 1 & AIII \\
\hline & & 1-methoxy propyl acetate & 50 & 1 & AII \\
\hline & & Cyclohexanone & 20 & 1 & - \\
\hline & & Butyl glycol & 50 & 1 & - \\
\hline & & Bipropylglycol & - & 2 & AII \\
\hline
\end{tabular}

A-very toxic material with ignition temperatures below $23^{\circ} \mathrm{C}$

$\mathrm{B}$ - organic matter with ignition temperature above $23{ }^{\circ} \mathrm{C}$ or non-flammable organic matter

I-explosive materials

II-gases or vapor under pressure, with a critical temperature lower than $50{ }^{\circ} \mathrm{C}$ and pressure higher than $300 \mathrm{kPa}$

III-flammable liquids with vapor pressure $<300 \mathrm{kPa}$ at $50{ }^{\circ} \mathrm{C}$, flash point lower than $100{ }^{\circ} \mathrm{C}$

${ }^{a}$ Short-term exposure limits

Table 2 Ecological characteristics of solvents for machine washing (Kiurski 2010)

\begin{tabular}{|c|c|c|c|c|}
\hline Detergent & $\begin{array}{l}\mathrm{MAC} \\
\left(\mathrm{mg} / \mathrm{m}^{3}\right)\end{array}$ & $\begin{array}{l}\text { Toxicity } \\
\text { category }\end{array}$ & $\begin{array}{l}\text { Flammability } \\
\text { class }\end{array}$ & $\begin{array}{l}\text { Ignition } \\
\text { temperature }\end{array}$ \\
\hline Special benzine & 350 & 2 & A I & $<21$ \\
\hline Test benzine (mixtures of aliphatic and cyclic hydrocarbon) & 350 & 2 & A II & $>21-55$ \\
\hline $\begin{array}{l}\text { Test benzine (mixtures of aliphatic and cyclic hydrocarbons with higher } \\
\text { ignition temperature) }\end{array}$ & & 1 & A III & $55-100$ \\
\hline Mineral and vegetable oils & & $0-1$ & & $>100$ \\
\hline
\end{tabular}

A-very toxic material with an ignition temperature below $23{ }^{\circ} \mathrm{C}$

I-explosive materials

II-gases or vapor under pressure, with a critical temperature lower than $50{ }^{\circ} \mathrm{C}$ and pressure higher than $300 \mathrm{kPa}$

III-flammable liquids with vapor pressure $<300 \mathrm{kPa}$ at $50{ }^{\circ} \mathrm{C}$ and flash point lower than $100{ }^{\circ} \mathrm{C}$

${ }^{\text {a }}$ Maximum allowed concentrations

ions are then separated and detected by the mass spectrometer. The sample is typically introduced into the ICP plasma as an aerosol, either by aspirating a liquid or dissolved solid sample into a nebulizer or using a laser to directly convert solid samples into an aerosol. Once the sample aerosol is introduced into the 
ICP torch, it is completely dissolved and the elements in the aerosol are converted first into gaseous atoms and then ionized toward the end of the plasma. Once the elements in the sample are converted into ions, they are then brought into the mass spectrometer via the interface cones. The interface region in the ICP-MS transmits the ions traveling in the argon sample stream at atmospheric pressure (1-2 torr) into the low pressure region of the mass spectrometer $\left(<1 \times 10^{-5}\right.$ torr $)$. This is done through the intermediate vacuum region created by the two interface cones, the sampler and the skimmer. The ions from the ICP source are then focused by the electrostatic lenses in the system. The ions coming from the system are positively charged, so the electrostatic lens, which also has a positive charge, serves to collimate the ion beam and focus it into the entrance aperture or slit of the mass spectrometer (Thomas 2013).

- A Mannix DLAF-8000 instrument to determine temperature, light intensity and relative humidity in the investigated indoor environments. The instrument is distinguished with low-friction ball bearing mounted wheel design, which provides high accuracy at high and low air velocity. It is characterized by high precision thin-film capacitance humidity sensor with fast response to the humidity changes. Features standard type $\mathrm{K}$ ( $\mathrm{NiCr}-\mathrm{NiAl})$ thermocouple input. Built-in microprocessor circuit assures accuracy, while multi channel display at the same time measures values of relative humidity, temperature, light intensity or air velocity (Fotronic Corporation 2015).

\section{Wastewater}

Four samples of waste printing inks (three conventional and one eco-solvent ink) from four different digital printing machines (Mimaki JV 3-250 SPF, Vutek Ultra VU II 3360, HPScitex XP 5300 and Roland SOL JET PRO III $\mathrm{XC}-540 \mathrm{MT}$ ) were analyzed in order to determine the concentrations of metal ions. All ink samples were from a digital printing facility in Novi Sad, Serbia.

Given the fact that after the development process printing developer is enriched by plate surface compounds such as novolac, organic polymeric binders, photosensitive compounds and dyes, the purification process of waste developer is required, in order to meet increasingly stringent environmental quality standards. Heavy metals found in a waste printing developer come from dye residue, and they tend to be accumulated in living organisms, causing numerous diseases and disorders (Kiurski et al. 2009, 2012d). The samples of fresh and waste printing developer were taken from an offset printing facility in Novi Sad,
Serbia. The adsorption of $\mathrm{Zn}$ (II) ions onto various adsorbents was studied in laboratory batch mode. Activated carbon (AC), natural zeolite-clinoptilolite-(NZ), a mixture of activated carbon and natural zeolite $(\mathrm{AC}+\mathrm{NZ})$, bentonite $(\mathrm{B})$, fired clay $(\mathrm{C})$ and modified clay with the addition of polyethylene glycol 600 (MC), were used with the aim of testing the removal efficiency of the $\mathrm{Zn}$ (II) ions from a waste printing developer (Kiurski et al. 2012a, 2013d).

\section{Ambient indoor air}

The campaign of indoor air sampling was carried out during 6 months owing effectively measurement of ozone and TVOCs in all 22 printing facilities of Novi Sad, Serbia. Air samples were collected and analyzed in situ 3 times during $4 \mathrm{~h}$, every $40 \mathrm{~min}$, nearby the appropriate printing machines in pad (PPF 1-5), screen (SPF 1-5), web-fed offset (WOPF 1 and 2), flexographic (FPF 1-5), and digital (DPF 1-5) printing facilities. The selected facilities within a particular printing technique are not similar in area, as well as used raw materials in printing process. The compatibility between facilities is only in the printing technique.

Temperature, relative humidity and light intensity measurements were carried out simultaneously during indoor air sampling.

The obtained results were used for further multiple linear regression analysis.

\section{Multiple linear regression analysis}

Regression is a statistical method that describes the relationship between different phenomena. As an extension of simple linear regression, multiple linear regression analysis allows researchers to answer questions that consider the roles that multiple independent variables play in accounting for variance in a single dependent variable. Importance of this method lies in the ability to predict the outcome of certain events based on knowledge of other phenomena. Phenomena on which the prediction is obtained, $X_{1}, X_{2}, \ldots$, $X_{\mathrm{k}}$, population, are independent (deterministic) variables or factors and their occurrence depend on these variables, $Y$ is called the dependent (stochastic) variable. The dependence of these phenomena is given in population regression model from Eq. 1:

$Y=P_{Y}\left(X_{1}, \ldots, X_{k}\right)+E, P_{Y}$ everywhere replaced by $\mu$

where $E$ is the random error.

Due to predict the outcome of certain events, the function defining the interdependent variables should be found. 
Table 3 Concentration levels of heavy metals in waste printing inks

\begin{tabular}{|c|c|c|c|c|c|}
\hline \multirow[t]{2}{*}{ Heavy metals } & \multirow[t]{2}{*}{$\mathrm{MAC}^{\mathrm{a}}(\mathrm{mg} / \mathrm{L})$} & \multicolumn{4}{|c|}{ Concentration (mg/L) } \\
\hline & & A & B & $\mathrm{C}$ & $\mathrm{D}$ \\
\hline $\mathrm{Cu}$ & 1 & 344 & 240 & 450 & 0.8 \\
\hline $\mathrm{Cd}$ & 0.1 & 0.01 & 0.01 & 0.01 & 0.01 \\
\hline $\mathrm{Fe}$ & 3 & 2.3 & 1 & 3.7 & 5.3 \\
\hline $\mathrm{Ag}$ & 0.5 & 0.1 & 0.1 & 0.1 & 0.1 \\
\hline $\mathrm{Cr}$ & 1 & 0.1 & 0.1 & 0.1 & 0.1 \\
\hline $\mathrm{Al}$ & 3 & 24 & 0.5 & 7 & 13 \\
\hline $\mathrm{Zn}$ & 2 & 4.3 & 4.3 & 4.2 & 1.3 \\
\hline
\end{tabular}

$\mathrm{A}, \mathrm{B}, \mathrm{C}-$ conventional waste printing inks

$\mathrm{D}$-eco-solvent waste printing ink

${ }^{\text {a }}$ Limits to drainage in the city sewage system according to the Water Law of the Republic of Serbia (Water Law of the Republic of Serbia 2010)

For multiple linear regressions, regression function of the population is the following (Eq. 2):

$P_{Y}\left(X_{1}, X_{2}, \ldots, X_{k}\right)=\beta_{0}+\beta_{1} X_{1}+\beta_{2} X_{2}+\cdots+\beta_{k} X_{k}$

where $\beta_{i}, i=0, \ldots, k$ is unknown regression coefficient, $X_{j}$, $j=1, \ldots, k$ is independent deterministic variable.

The difference between the actual value of the dependent factor $Y$ and predicted values of the population is prediction error. Mistakes are almost always different from 0 , so it is necessary to find the function for which they are minimal (Vukadinić and Popović 2004; Vuković 2007; Kiurski et al. 2013a).

\section{Results and discussion}

\section{Quantification of hazards in the printing industry of Novi Sad}

The analysis of waste inks confirmed the presence of copper, cadmium, iron, silver, chromium, and zinc in all samples (Table 3).

Variations of the metal concentrations were from $0.01 \mathrm{mg} / \mathrm{L}$ for $\mathrm{Cd}$ to $450 \mathrm{mg} / \mathrm{L}$ for $\mathrm{Cu}$ (Table 3). Copper has the highest variation of the concentration levels (a range of $0.8-450 \mathrm{mg} / \mathrm{L}$ ) due to the type of waste printing ink. The Water Law and associated sub-legal acts of Republic of Serbia prescribed the MACs for the drainage of hazardous matters in the city sewage system for $\mathrm{Cu}$ of $1 \mathrm{mg} / \mathrm{L}, \mathrm{Cd}$ of $0.1 \mathrm{mg} / \mathrm{L}, \mathrm{Fe}$ of $3 \mathrm{mg} / \mathrm{L}, \mathrm{Ag}$ of $0.5 \mathrm{mg} / \mathrm{L}, \mathrm{Cr}$ of $1 \mathrm{mg} / \mathrm{L}, \mathrm{Al}$ of $3 \mathrm{mg} / \mathrm{L}$ and $\mathrm{Zn}$ of $2 \mathrm{mg} / \mathrm{L}$ (Water Law of the Republic of Serbia 2012).

The highest concentration of zinc is observed in conventional waste inks (A, B and C) in relation to the ecosolvent waste ink D (Table 3). However, the metal concentrations, except copper and zinc are below the MAC values prescribed by Water Law of Serbia.
Solving the problem of printing wastewater pollution was successfully performed with the adsorption method using different adsorbents. The purification efficiency was monitored during the specified contact time. Based on the obtained results, the mechanism of $\mathrm{Zn}$ (II) ion separation was determined. The results indicated the effectiveness of the adsorbent in the following order: $\mathrm{MC}>\mathrm{C}>\mathrm{B}>\mathrm{AC}>\mathrm{NZ}>\mathrm{AC}+\mathrm{NZ}$, Table 4 (Kiurski et al. 2012a, b, 2013d).

The preliminary monitoring of ambient air quality confirmed the presence of ozone and total volatile organic compounds. The maximal ozone and TVOCs average concentrations for each printing technique are presented in Fig. 1.

It was observed that ozone and TVOCs concentrations varied depending on the type of printing technique. Variations are related to the chemical composition of the raw materials used, the ambient conditions, and the type of installed air ventilation in the printing machine (Kiurski et al. 2011).

The highest average ozone concentration, $1.0155 \mathrm{ppm}$, was detected in a screen-printing facility (SPF). Web-fed offset printing (WOPF) is characterized by highest TVOCs concentration of $59.6 \mathrm{ppm}$. The Occupational Safety and Health Administration (OSHA) recommends $0.1 \mathrm{ppm}$ as a permissible exposure limit (PEL) for an 8-h time-weighted average (TWA) exposure to ozone (OSHA 2015). The PEL values for TVOCs have not yet been adopted. Based on the obtained results, it can be concluded that the average concentration levels of ozone in all of the investigated printing facilities were above the PEL values, except in the web-fed offset printing facility.

The experimental results also showed the significant increase in ambient ozone concentration with the increase in TVOCs concentrations in pad and screen-printing facilities due to the usage of solvent-based inks and UV lamps during the printing process. 
Table 4 The concentration of $\mathrm{Zn}$ (II) ion in the offset printing developer before and after adsorption

Before adsorption (mg/L $\pm \mathrm{RD})$

\begin{tabular}{llllll}
\hline Pure developer & & Waste developer \\
\hline $1.278 \pm 0.064$ & & & $17.302 \pm 0.865$ \\
\hline After adsorption $(\mathrm{mg} / \mathrm{L} \pm \mathrm{RD})$ & $\mathrm{B}$ & $\mathrm{C}$ & $\mathrm{MC}$ \\
\hline $\mathrm{AC}$ & $\mathrm{NZ}$ & $\mathrm{AC}+\mathrm{NZ}$ & $\mathrm{B}$ & $1.963 \pm 0.098$
\end{tabular}

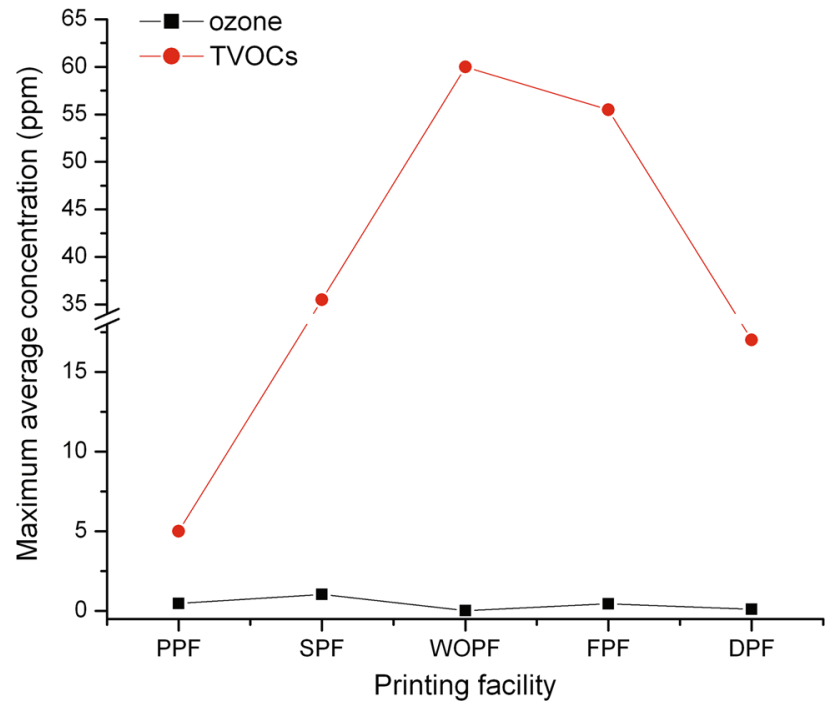

Fig. 1 Maximum average concentrations of ozone and TVOCs in various printing techniques

The obtained experimental data set served as a good basis for the application of multiple linear regression analysis.

Furthermore, a comparison of obtained monitoring results might be done with the results of Caselli et al. (2009). Caselli et al. (2009) reported that TVOCs concentrations weekly varied from 415.8 to $1823.3 \mu \mathrm{g} / \mathrm{m}^{3}$ in 16 investigated newspaper stands. In contrast, TVOC concentrations in the printing shops were lower than the average level monitored in the newspaper stands. Also, registered TVOC concentrations in the different environments of the printing shops showed more similar trend with the TVOCs concentrations present in the newspaper stands equipped air conditioners. The monitoring in two printing shops and the comparison among the VOC concentrations in the different environments confirmed that the newspapers and the ink are the sources of these indoor levels. Therefore, in order to reduce the impact on newsagents, Caselli et al. (2009) recommended the development of new inks that contain non-toxic ingredients or the use of waterbased inks already present in commerce.

\section{Multiple linear regression analysis}

Multiple linear regression analysis was performed on the obtained average values, Table 5 , in order to determine the mutual correlation between the hazardous pollutants (ozone and TVOCs) and microclimate parameters: temperature $(\mathrm{t})$, relative humidity $(\mathrm{RH})$ and light intensity (LI). Ozone and TVOCs concentrations were selected as dependent variables, while microclimates parameters were independent variables. The obtained regression models express the quantitative correlation of the examined phenomena and indicate the strength of the agreement.

The reliability prediction of the used regression models is a function of the standard error of the regression magnitude. The standard error of regression (SD) is an absolute measure of sampling data variation obtained from the regression model. It shows the average deviation of the regression line from the empirical relationships of the observed phenomena (Vuković 2007).

The multiple coefficient of determination is a measure that indicates the relative degree of linear agreement between dependent and independent variables. The coefficient value can be between 0 and 1 , and higher linear agreement is achieved if the value is closer to 1 . The significance of a regression coefficient in a regression model is determined by dividing the estimated coefficient over the standard deviation of this estimate. For statistical significance, we expect the absolute value of the $t$-ratio to be $>2$ (in our case, $t_{\text {critical }}=2.9200$ ) or to be less than the significance level $(\alpha=0.01,0.05$ or 0.1$)$. In considering the significance of the t-values, we assume that all other variables are part of the model.

The risk of error denoted by $\alpha$ in our case amount $\alpha=0.05$. Risk is amended to provide the reliability coefficient, which is equal to $(1-\alpha)=1-0.05=0.095$. Both values are often expressed in percent, which are named confidence level (Žižić et al. 2006). 
Table 5 Average concentrations of ozone and TVOCs in all press facilities

\begin{tabular}{|c|c|c|c|c|c|c|c|}
\hline \multirow[t]{2}{*}{ Press facility } & \multirow[t]{2}{*}{ Pollutant } & \multicolumn{6}{|c|}{ Sampling time (min) } \\
\hline & & 40 & 80 & 120 & 160 & 200 & 240 \\
\hline \multicolumn{8}{|c|}{ Average concentration ( } \\
\hline \multirow[t]{2}{*}{ PPF1 } & Ozone & 0.014 & 0.014 & 0.023 & 0.018 & 0.028 & 0.023 \\
\hline & TVOCs & 0.230 & 0.320 & 0.150 & 0.080 & 0.100 & 0.050 \\
\hline \multirow[t]{2}{*}{ PPF2 } & Ozone & 0.720 & 1.482 & 0.178 & 0.122 & 0.226 & 0.066 \\
\hline & TVOCs & 3.580 & 3.690 & 6.780 & 6.800 & 8.100 & 3.040 \\
\hline \multirow[t]{2}{*}{ PPF3 } & Ozone & 0.005 & 0.009 & 0.004 & 0.003 & 0.005 & 0.004 \\
\hline & TVOCs & 2.140 & 0.750 & 0.560 & 0.510 & 0.730 & 0.650 \\
\hline \multirow[t]{2}{*}{ PPF4 } & Ozone & 0.016 & 0.021 & 0.020 & 0.026 & 0.028 & 0.026 \\
\hline & TVOCs & 0.430 & 0.580 & 1.050 & 0.670 & 0.990 & 0.770 \\
\hline \multirow[t]{2}{*}{ PPF5 } & Ozone & 0.007 & 0.010 & 0.012 & 0.014 & 0.009 & 0.015 \\
\hline & TVOCs & 0.210 & 0.120 & 0.320 & 0.220 & 0.110 & 0.080 \\
\hline \multirow[t]{2}{*}{ SPF 1} & Ozone & 0.051 & 0.099 & 0.168 & 0.124 & 0.142 & 0.112 \\
\hline & TVOCs & 0.438 & 0.461 & 0.329 & 0.397 & 0.318 & 0.418 \\
\hline \multirow[t]{2}{*}{ SPF 2} & Ozone & 2.391 & 0.627 & 0.726 & 0.769 & 0.860 & 0.696 \\
\hline & TVOCs & 2.807 & 7.054 & 10.020 & 10.778 & 12.614 & 14.590 \\
\hline \multirow[t]{2}{*}{ SPF 3} & Ozone & 0.000 & 0.000 & 0.000 & 0.000 & 0.000 & 0.000 \\
\hline & TVOCs & 0.422 & 0.693 & 2.237 & 23.830 & 172.000 & 13.700 \\
\hline \multirow[t]{2}{*}{ SPF 4} & Ozone & 0.000 & 0.296 & 0.108 & 0.025 & 0.000 & 0.000 \\
\hline & TVOCs & 1.085 & 0.490 & 25.158 & 1.242 & 0.311 & 1.279 \\
\hline \multirow[t]{2}{*}{ SPF 5} & Ozone & 0.000 & 0.000 & 0.000 & 0.000 & 0.000 & 0.000 \\
\hline & TVOCs & 1.537 & 2.815 & 3.905 & 14.154 & 35.599 & 80.352 \\
\hline \multirow[t]{2}{*}{ WOPF 1} & Ozone & 0.006 & 0.009 & 0.011 & 0.015 & 0.012 & 0.019 \\
\hline & TVOCs & 18.030 & 32.120 & 48.230 & 22.260 & 15.400 & 10.080 \\
\hline \multirow[t]{2}{*}{ WOPF 2} & Ozone & 0.016 & 0.018 & 0.015 & 0.012 & 0.018 & 0.016 \\
\hline & TVOCs & 63.210 & 75.130 & 77.890 & 55.330 & 47.910 & 38.140 \\
\hline \multirow[t]{2}{*}{ FPF 1} & Ozone & 0.007 & 0.004 & 0.008 & 0.019 & 0.023 & 0.080 \\
\hline & TVOCs & 0.000 & 3.070 & 5.000 & 8.500 & 9.960 & 0.750 \\
\hline \multirow[t]{2}{*}{ FPF 2} & Ozone & 0.009 & 0.011 & 0.012 & 0.013 & 0.015 & 0.013 \\
\hline & TVOCs & 5.400 & 11.860 & 6.970 & 7.730 & 10.610 & 0.520 \\
\hline \multirow[t]{2}{*}{ FPF 3} & Ozone & 0.104 & 0.607 & 0.181 & 0.268 & 0.025 & 0.459 \\
\hline & TVOCs & 102.570 & 21.220 & 32.080 & 96.870 & 79.610 & 0.760 \\
\hline \multirow[t]{2}{*}{ FPF 4} & Ozone & 0.008 & 0.005 & 0.125 & 0.155 & 0.198 & 0.205 \\
\hline & TVOCs & 23.770 & 49.080 & 39.300 & 29.340 & 97.060 & 2.450 \\
\hline \multirow[t]{2}{*}{ FPF 5} & Ozone & 0.215 & 0.140 & 0.31 & 0.457 & 0.699 & 0.899 \\
\hline & TVOCs & 31.580 & 48.880 & 42.610 & 36.300 & 29.900 & 20.070 \\
\hline \multirow[t]{2}{*}{ DPF1 } & Ozone & 0.006 & 0.015 & 0.017 & 0.018 & 0.014 & 0.017 \\
\hline & TVOCs & 1.460 & 2.030 & 3.080 & 3.570 & 4.390 & 5.190 \\
\hline DPF2 & Ozone & 0.005 & 0.004 & 0.004 & 0.013 & 0.005 & 0.006 \\
\hline & TVOCs & 36.150 & 12.660 & 11.370 & 10.880 & 17.250 & 8.770 \\
\hline DPF3 & Ozone & 0.012 & 0.017 & 0.027 & 0.041 & 0.021 & 0.043 \\
\hline & TVOCs & 0.090 & 0.110 & 0.070 & 0.050 & 0.120 & 0.040 \\
\hline DPF4 & Ozone & 0.000 & 0.003 & 0.003 & 0.005 & 0.010 & 0.011 \\
\hline & TVOCs & 0.030 & 0.000 & 0.050 & 0.070 & 0.100 & 0.030 \\
\hline DPF5 & Ozone & 0.089 & 0.494 & 0.105 & 0.013 & 0.000 & 0.000 \\
\hline & TVOCs & 1.220 & 2.120 & 1.050 & 1.220 & 1.960 & 2.020 \\
\hline
\end{tabular}


Table 5 continued

\begin{tabular}{|c|c|c|c|c|c|c|c|}
\hline \multirow[t]{2}{*}{ Press facility } & \multirow[t]{2}{*}{ Microclimate parameter } & \multicolumn{6}{|c|}{ Sampling time (min) } \\
\hline & & 40 & 80 & 120 & 160 & 200 & 240 \\
\hline \multicolumn{8}{|c|}{ Average microclimate parameters } \\
\hline \multirow[t]{3}{*}{ PPF1 } & $t\left({ }^{\circ} \mathrm{C}\right)$ & 21.2 & 20.6 & 19.7 & 20.1 & 20.4 & 20.7 \\
\hline & $\mathrm{RH}^{*}(\%)$ & 31.8 & 34.4 & 38.0 & 38.7 & 38.4 & 37.5 \\
\hline & $\mathrm{LI}^{* *}(\mathrm{~lx})$ & 200 & 208 & 245 & 230 & 217 & 239 \\
\hline \multirow[t]{3}{*}{ PPF2 } & $t\left({ }^{\circ} \mathrm{C}\right)$ & 19.1 & 18.6 & 19.7 & 22.6 & 20.6 & 22.4 \\
\hline & $\mathrm{RH}^{*}(\%)$ & 36.1 & 37.2 & 36.8 & 36.2 & 37.7 & 35.2 \\
\hline & $\mathrm{LI}^{* *}(\mathrm{~lx})$ & 246 & 191 & 372 & 397 & 263 & 456 \\
\hline \multirow[t]{3}{*}{ PPF3 } & $t\left({ }^{\circ} \mathrm{C}\right)$ & 21.9 & 21.4 & 21.4 & 22.4 & 24.0 & 23.8 \\
\hline & $\mathrm{RH}^{*}(\%)$ & 33.2 & 32.9 & 33.3 & 29.0 & 28.6 & 29.2 \\
\hline & $\mathrm{LI}^{* *}(\mathrm{~lx})$ & 222 & 252 & 220 & 239 & 250 & 251 \\
\hline \multirow[t]{3}{*}{ PPF4 } & $t\left({ }^{\circ} \mathrm{C}\right)$ & 23.2 & 23.5 & 23.7 & 23.7 & 24.9 & 25.6 \\
\hline & $\mathrm{RH}^{*}(\%)$ & 44.3 & 42.3 & 42.0 & 41.1 & 39.9 & 37.8 \\
\hline & $\mathrm{LI}^{* *}(\mathrm{~lx})$ & 467 & 488 & 505 & 448 & 439 & 429 \\
\hline \multirow[t]{3}{*}{ PPF5 } & $t\left({ }^{\circ} \mathrm{C}\right)$ & 23.7 & 24.4 & 24.4 & 24.5 & 24.8 & 24.6 \\
\hline & $\mathrm{RH}^{*}(\%)$ & 32.0 & 31.4 & 31.5 & 30.7 & 30.8 & 30.9 \\
\hline & $\mathrm{LI}^{* *}(\mathrm{~lx})$ & 413 & 557 & 494 & 440 & 430 & 324 \\
\hline \multirow[t]{3}{*}{ SPF 1} & $t\left({ }^{\circ} \mathrm{C}\right)$ & 19.5 & 20.5 & 19.6 & 19.3 & 19.3 & 21.3 \\
\hline & $\mathrm{RH}^{*}(\%)$ & 42.0 & 43.1 & 45.6 & 44.3 & 43.2 & 41.3 \\
\hline & $\mathrm{LI}^{* *}(\mathrm{~lx})$ & 99 & 238 & 357 & 408 & 870 & 416 \\
\hline \multirow[t]{3}{*}{ SPF 2} & $t\left({ }^{\circ} \mathrm{C}\right)$ & 22.8 & 22.7 & 22.3 & 22.9 & 23.6 & 22.9 \\
\hline & $\mathrm{RH}^{*}(\%)$ & 52.0 & 46.6 & 49.4 & 46.4 & 44.3 & 45.5 \\
\hline & $\mathrm{LI}^{* *}(\mathrm{~lx})$ & 74 & 107 & 402 & 84 & 255 & 173 \\
\hline \multirow[t]{3}{*}{ SPF 3} & $t\left({ }^{\circ} \mathrm{C}\right)$ & 21.6 & 22.5 & 22.1 & 22.1 & 22.8 & 22.0 \\
\hline & $\mathrm{RH}^{*}(\%)$ & 44.0 & 44.3 & 43.6 & 43.1 & 42.8 & 45.4 \\
\hline & $\mathrm{LI}^{* *}(\mathrm{~lx})$ & 150 & 60 & 222 & 232 & 270 & 174 \\
\hline \multirow[t]{3}{*}{ SPF 4} & $t\left({ }^{\circ} \mathrm{C}\right)$ & 27.3 & 27.4 & 26.5 & 26.2 & 27.8 & 28.8 \\
\hline & $\mathrm{RH}^{*}(\%)$ & 48.5 & 48.6 & 48.5 & 48.0 & 55.2 & 45.6 \\
\hline & $\mathrm{LI}^{* *}(\mathrm{~lx})$ & 905 & 822 & 1088 & 1885 & 916 & 1186 \\
\hline \multirow[t]{3}{*}{ SPF 5} & $t\left({ }^{\circ} \mathrm{C}\right)$ & 23.3 & 21.1 & 20.3 & 21.0 & 21.7 & 21.3 \\
\hline & $\mathrm{RH}^{*}(\%)$ & 47.9 & 52.6 & 56.7 & 55.0 & 56.2 & 54.2 \\
\hline & $\mathrm{LI}^{* *}(\mathrm{~lx})$ & 83 & 232 & 143 & 112 & 294 & 189 \\
\hline \multirow[t]{3}{*}{ WOPF 1} & $t\left({ }^{\circ} \mathrm{C}\right)$ & 23.9 & 24.7 & 25.9 & 25.8 & 25.1 & 25.3 \\
\hline & $\mathrm{RH}^{*}(\%)$ & 46.4 & 43.0 & 44.4 & 41.7 & 41.4 & 43.3 \\
\hline & $\mathrm{LI}^{* *}(\mathrm{~lx})$ & 46 & 62 & 61 & 57 & 55 & 43 \\
\hline \multirow[t]{3}{*}{ WOPF 2} & $t\left({ }^{\circ} \mathrm{C}\right)$ & 27.6 & 27.3 & 28.8 & 27.4 & 27.8 & 27.6 \\
\hline & $\mathrm{RH}^{*}(\%)$ & 38.6 & 36.4 & 34.6 & 34.9 & 33.8 & 33.4 \\
\hline & $\mathrm{LI}^{* *}(\mathrm{~lx})$ & 100 & 100 & 99 & 102 & 103 & 99 \\
\hline \multirow[t]{3}{*}{ FPF 1} & $t\left({ }^{\circ} \mathrm{C}\right)$ & 21.8 & 23.2 & 23.0 & 22.2 & 19.3 & 18.1 \\
\hline & $\mathrm{RH}^{*}(\%)$ & 46.1 & 43.5 & 44.8 & 47.0 & 53.2 & 50.0 \\
\hline & $\mathrm{LI}^{* *}(\mathrm{~lx})$ & 109 & 112 & 98 & 99 & 96 & 81 \\
\hline \multirow[t]{3}{*}{ FPF 2} & $t\left({ }^{\circ} \mathrm{C}\right)$ & 13.5 & 13.8 & 10.8 & 12.9 & 11.8 & 12.1 \\
\hline & $\mathrm{RH}^{*}(\%)$ & 29.6 & 37.1 & 44.0 & 38.6 & 38.7 & 39.6 \\
\hline & $\mathrm{LI}^{* *}(\mathrm{~lx})$ & 74 & 98 & 121 & 144 & 104 & 179 \\
\hline \multirow[t]{3}{*}{ FPF 3} & $t\left({ }^{\circ} \mathrm{C}\right)$ & 10.7 & 11.5 & 11.7 & 11.6 & 13.1 & 13.3 \\
\hline & $\mathrm{RH}^{*}(\%)$ & 25.2 & 31.8 & 25.5 & 27.1 & 27.8 & 25.5 \\
\hline & LI** (lx) & 87 & 68 & 81 & 105 & 88 & 92 \\
\hline
\end{tabular}


Table 5 continued

\begin{tabular}{|c|c|c|c|c|c|c|c|}
\hline \multirow[t]{2}{*}{ Press facility } & \multirow[t]{2}{*}{ Microclimate parameter } & \multicolumn{6}{|c|}{ Sampling time (min) } \\
\hline & & 40 & 80 & 120 & 160 & 200 & 240 \\
\hline \multirow[t]{3}{*}{ FPF 4} & $t\left({ }^{\circ} \mathrm{C}\right)$ & 17.7 & 17.0 & 16.6 & 16.3 & 16.5 & 16.6 \\
\hline & $\mathrm{RH}^{*}(\%)$ & 28.0 & 29.6 & 30.6 & 30.4 & 29.2 & 29.6 \\
\hline & $\mathrm{LI}^{* *}(\mathrm{~lx})$ & 441 & 430 & 405 & 388 & 358 & 352 \\
\hline \multirow[t]{3}{*}{ FPF 5} & $t\left({ }^{\circ} \mathrm{C}\right)$ & 27.9 & 27.9 & 29.2 & 30.6 & 29.9 & 30.1 \\
\hline & $\mathrm{RH}^{*}(\%)$ & 24.1 & 24.0 & 25.3 & 23.3 & 25.5 & 23.2 \\
\hline & $\mathrm{LI} * *(1 \mathrm{x})$ & 45 & 65 & 48 & 66 & 53 & 63 \\
\hline \multirow[t]{3}{*}{ DPF 1} & $t\left({ }^{\circ} \mathrm{C}\right)$ & 21.9 & 22.8 & 24.1 & 24.8 & 25.0 & 25.1 \\
\hline & $\mathrm{RH}^{*}(\%)$ & 33.7 & 33.0 & 30.6 & 30.2 & 29.4 & 28.8 \\
\hline & $\mathrm{LI}^{* *}(\mathrm{~lx})$ & 100 & 100 & 98 & 99 & 96 & 94 \\
\hline \multirow[t]{3}{*}{ DPF 2} & $t\left({ }^{\circ} \mathrm{C}\right)$ & 17.5 & 20.0 & 22.3 & 22.8 & 24.6 & 24.5 \\
\hline & $\mathrm{RH}^{*}(\%)$ & 35.0 & 32.7 & 31.6 & 32.1 & 30.7 & 30.1 \\
\hline & $\mathrm{LI}^{* *}(\mathrm{~lx})$ & 347 & 363 & 366 & 359 & 347 & 343 \\
\hline \multirow[t]{3}{*}{ DPF 3} & $t\left({ }^{\circ} \mathrm{C}\right)$ & 24.3 & 24.3 & 24.7 & 25.4 & 24.7 & 25.6 \\
\hline & $\mathrm{RH}^{*}(\%)$ & 32.8 & 34.8 & 33.6 & 33.7 & 33.8 & 32.4 \\
\hline & $\mathrm{LI}^{* *}(\mathrm{~lx})$ & 204 & 222 & 237 & 221 & 207 & 274 \\
\hline \multirow[t]{3}{*}{ DPF 4} & $t\left({ }^{\circ} \mathrm{C}\right)$ & 23.9 & 24.8 & 26.6 & 27.3 & 26.8 & 27.8 \\
\hline & $\mathrm{RH}^{*}(\%)$ & 46.4 & 48.7 & 42.6 & 39.7 & 39.8 & 38.6 \\
\hline & $\mathrm{LI}^{* *}(\mathrm{~lx})$ & 491 & 525 & 577 & 649 & 501 & 540 \\
\hline \multirow[t]{3}{*}{ DPF 5} & $t\left({ }^{\circ} \mathrm{C}\right)$ & 26.8 & 28.4 & 28.6 & 29.0 & 29.1 & 29.2 \\
\hline & $\mathrm{RH}^{*}(\%)$ & 38.1 & 36.2 & 35.1 & 34.4 & 34.1 & 33.6 \\
\hline & LI** (lx) & 104 & 112 & 109 & 111 & 108 & 106 \\
\hline
\end{tabular}

$R H^{*}$ relative humidity, $L I^{* *}$ light intensity

Due to the highest correlation coefficient, ternary graphs of the target printing facilities were constructed by using the software package STATISTICA 10, (Figs. 2, 3, 4, 5, 6). The legend on each figure represents the values of the dependent variable $\mathrm{y}$, given to the resulting regression model. Color changing on the regression surface is associated with observed dependent of ozone and TVOC concentrations and independent (temperature, relative humidity and light intensity) variables. Decreasing of y values below the maxima, Figs. 2, 3, 4, 5 and 6, characterize the falling dependence between the observed variables which is resulted by the colors difference on the regression surface.

\section{Pad printing}

Multiple coefficients of determination $\left(R^{2}\right)$ indicate the strength of agreement between the variables $(t, \mathrm{RH}, \mathrm{LI}$, ozone and TVOCs concentration). The highest $R^{2}$ values are observed in PPF 2-4 and PPF 1 and 2 (Table 6).

Based on the obtained results, it can be concluded that there is a strong correlation between the observed phenomena. The decrease in coefficients of determination at the sampling locations PPF 1 and PPF 5 and PPF 3-5 (Table 6) contributed to a medium correlation between the observed phenomena.

The standard error of regression had the highest values in PPF 2 and PPF 3 (Table 6). SD values indicate that it is a less reliable prediction based on the obtained regression models.

Values $|t|>t_{\text {critical }}$ occur only at the sampling location in PPF 2 (Table 6). For all other sampling locations, the obtained values of parameter $|t|$ are smaller than $t_{\text {critical }}$, so there is not enough evidence to confirm the correlation between the parameters.

Figure 2 represents the spatial dependence of ozone concentrations on three independent variables-temperature, relative humidity and light intensity in PPF 3 . The $y$ values $>0$ (Fig. 2) show the highest dependence between ozone concentrations and microclimate parameters.

\section{Screen-printing}

Multiple coefficients of determination in the screen-printing facilities (SPF 1-3, Table 7) indicate a strong correlation between the studied phenomena. 


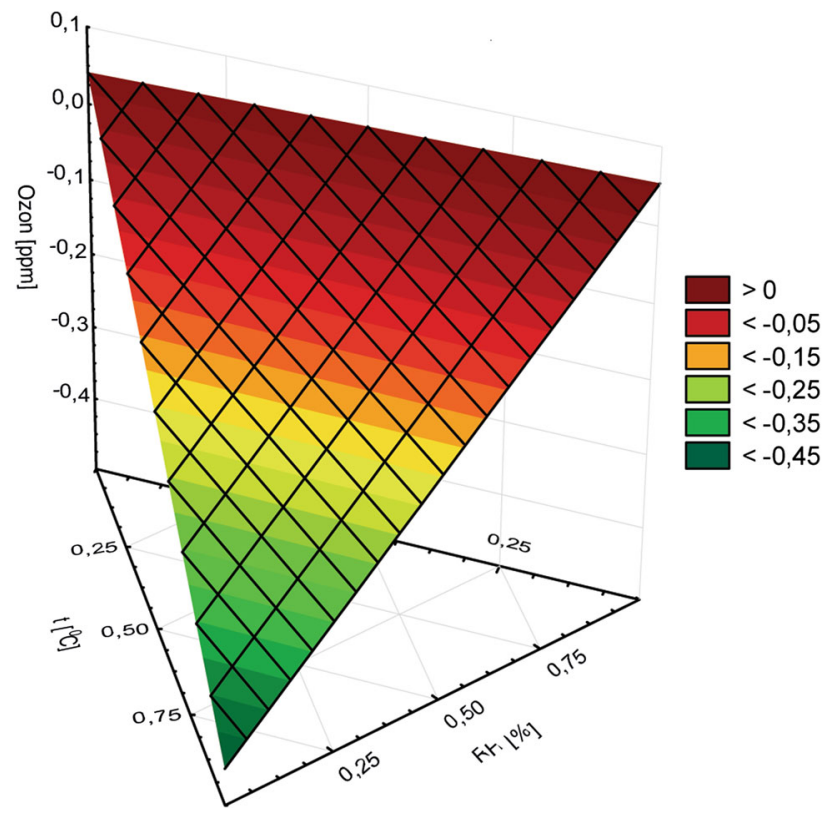

Fig. 2 Ternary graph of regressive surface in PPF 3 (dependence of temperature, light intensity, relative humidity and ozone concentrations)

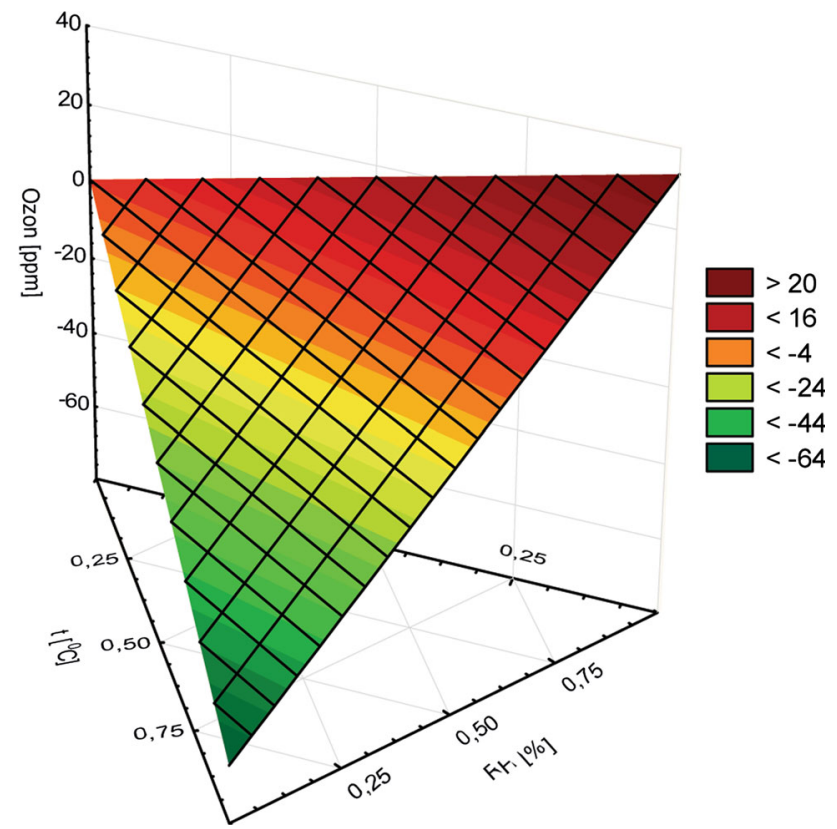

Fig. 3 Ternary graph of regressive surface in SPF 2 (dependence of temperature, light intensity, relative humidity and ozone concentrations)

Medium correlations were observed between microclimates parameters and ozone concentrations in SPF 4 $(0.6118)$ as well as microclimates parameters and TVOCs concentrations in SPF $4(0.5755)$ and SPF 5 (0.4363), Table 7.

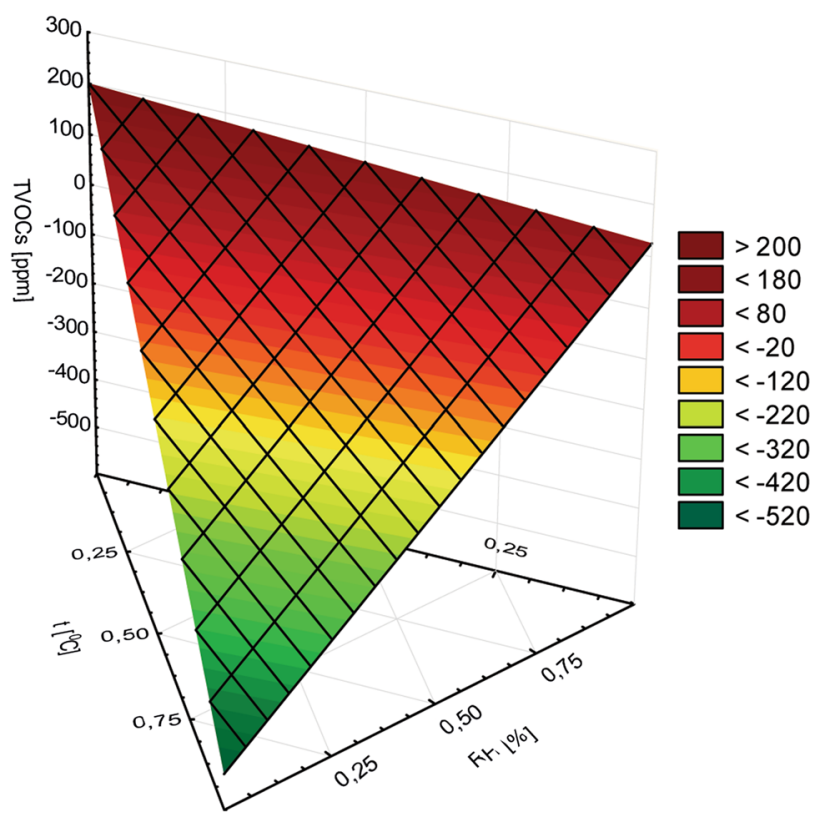

Fig. 4 Ternary graph of regressive surface in WOPF 1 (dependence of temperature, light intensity, relative humidity and TVOCs concentrations)

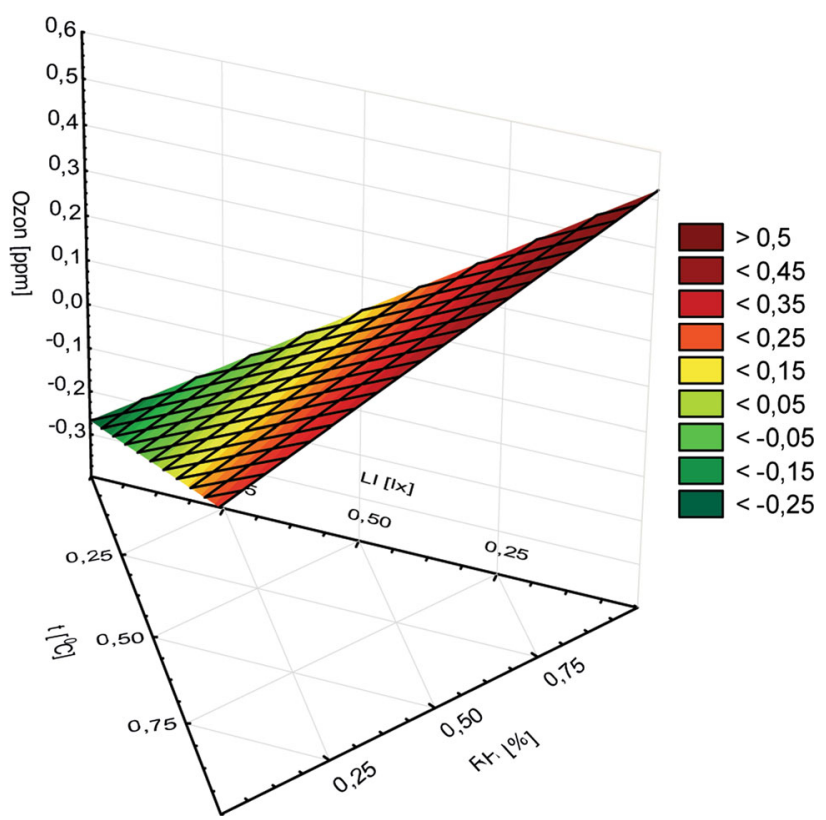

Fig. 5 Ternary graph of regressive surface in FPF 1 (dependence of temperature, light intensity, relative humidity and ozone concentrations)

The standard error of regression was large, especially in SPF 2-5, during the examination of the dependence between $t, \mathrm{RH}, \mathrm{LI}$ and TVOCs concentrations. The highest SD values (Table 7) indicate that it is a less reliable prediction based on the obtained regression models. 


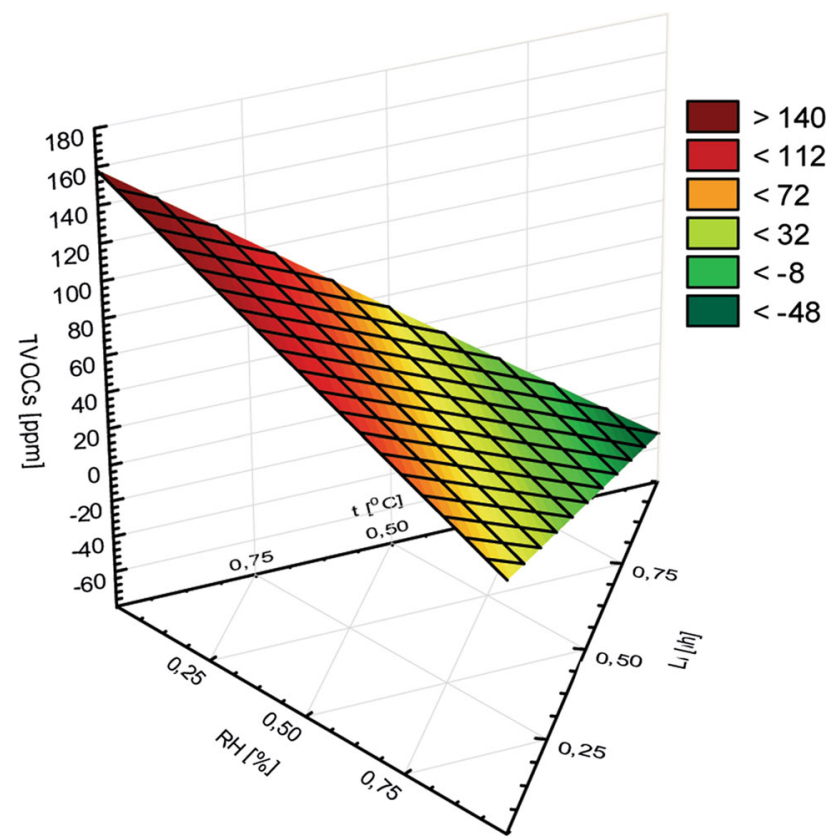

Fig. 6 Ternary graph of regressive surface in DPF 1 (dependence of temperature, light intensity, relative humidity and TVOCs concentrations)

Values of $|t|>t_{\text {critical }}$ appear at the sampling locations SPF 1 and SPF 2 during the examination of the dependence of microclimate parameters and ozone concentrations. All other obtained values of parameter |t|, for both investigated dependences, were smaller than $t_{\text {critical }}$, which is not sufficient to confirm the correlation between the parameters.
Figure 3 represents the spatial dependence of ozone concentrations on three independent variables-temperature, relative humidity and light intensity in SPF 2 . The $y$ values $>20$ (Fig. 3) show the highest dependence between ozone concentrations and microclimate parameters.

\section{Web-fed offset printing}

High multiple coefficients of determination in web-fed offset printing were $0.9553-\mathrm{WOPF} 1$, and 0.9928 and 0.9887-WOPF $1-2$, (Table 8), indicating a strong correlation between the phenomena.

The dependence between $t$, RH, LI and ozone concentration in WOPF 2 (Table 8) shows a weak correlation between the observed phenomena.

The standard error of regression had the highest values in WOPF 1 and WOPF 2 (Table 8). Based on the used regression models, the prediction is less reliable.

Observing the relationship between parameter $|t|$ and $t_{\text {critical }}$, it can be concluded that only at sampling location WOPF 1, (Table 8), values of $|t|$ are higher than $t_{\text {critical }}$. At sampling location WOPF 2, however, the obtained $|t|$ value was $<t_{\text {critical }}$. This is in accordance with previous conclusions, so there is a weak correlation between the parameters.

Figure 4 represents the spatial dependence of TVOCs concentrations on three independent variables-temperature, relative humidity and light intensity in WOPF 1 . The $y$ values $>200$ (Fig. 4) show the highest dependence between TVOCs concentrations and microclimate parameters.

Table 6 Dependence of temperature, humidity, light intensity on ozone and TVOCs concentrations

\begin{tabular}{llllll}
\hline Pollutant & Sampling location & $\begin{array}{l}\text { Multiple coefficient } \\
\text { of determination }\end{array}$ & SD & $t$ & Regression model \\
\hline Ozone & PPF 1 & 0.7934 & 0.2112 & -0.6662 & $\hat{y}=-0.1407+0.371 x_{1}+1.03 x_{2}+0.032 x_{3}$ \\
& PPF 2 & 0.8821 & 11.1302 & 1.1079 & $\hat{y}=12.3314-0.21 x_{1}-0.39 x_{2}-0.92 x_{3}$ \\
& PPF 3 & 0.9558 & 0.0301 & 2.0330 & $\hat{y}=-0.0613-0.02 x_{1}+1.09 x_{2}+1.06 x_{3}$ \\
& PPF 4 & 0.9047 & 0.2049 & 1.3395 & $\hat{y}=0.2745-0.88 x_{1}-1.4 x_{2}-0.35 x_{3}$ \\
& PPF 5 & 0.6691 & 2.4637 & 2.2932 & $\hat{y}=5.6497-0.85 x_{1}-x_{2}-0.5 x_{3}$ \\
TVOCs & PPF 1 & 0.9211 & 37.0107 & -3.071 & $\hat{y}=-113.6590+0.301 x_{1}+1.21 x_{2}+0.639 x_{3}$ \\
& PPF 2 & 0.9153 & 22.5896 & -0.622 & $\hat{y}=-14.0513+0.856 x_{1}+0.989 x_{2}-0.35 x_{3}$ \\
& PPF3 & 0.6664 & 16.7906 & -0.2579 & $\hat{y}=-4.3303+0.643 x_{1}-0.43 x_{2}+0.803 x_{3}$ \\
& PPF 4 & 0.7435 & 16.1471 & 0.1675 & $\hat{y}=2.7041-0.41 x_{1}-0.05 x_{2}+0.333 x_{3}$ \\
\hline
\end{tabular}

$x_{1}$ temperature, $x_{2}$ relative humidity, $x_{3}$ light intensity, $y$ ozone and TVOCs concentration 
Table 7 Dependence of temperature, humidity, light intensity on ozone and TVOCs concentrations

\begin{tabular}{llllll}
\hline Pollutant & Sampling location & $\begin{array}{l}\text { Multiple coefficient } \\
\text { of determination }\end{array}$ & SD & $t$ & Regression model \\
\hline Ozone & SPF 1 & 0.9818 & 0.3080 & -4.735 & $\hat{y}=-1.459+0.51 x_{1}+0.931 x_{2}+0.614 x_{3}$ \\
& SPF 2 & 0.9906 & 5.8141 & -6.535 & $\hat{y}=-37.9967+0.6971 x_{1}+1.19 x_{2}-0.17 x_{3}$ \\
& SPF 3 & - & - & - & - \\
& SPF 4 & 0.6118 & 2.8358 & 0.9694 & $\hat{y}=2.7490-0.52 x_{1}-0.36 x_{2}-0.70 x_{3}$ \\
TVOCs & - & - & - & - \\
& SPF 5 & SPF 1 & 1.0735 & 0.8905 & $\hat{y}=0.9559+0.122 x_{1}-0.42 x_{2}-0.67 x_{3}$ \\
& SPF 2 & 0.8916 & 117.7150 & 0.8273 & $\hat{y}=97.3820-0.13 x_{1}-0.87 x_{2}+0.326 x_{3}$ \\
& SPF 3 & 0.8934 & 51.4079 & -0.9407 & $\hat{y}=-2237.5865+0.623 x_{1}-0.02 x_{2}+0.499 x_{3}$ \\
& SPF 4 & 0.8764 & 247.1309 & 1.007 & $\hat{y}=247.3076-0.65 x_{1}-0.28 x_{2}-0.42 x_{3}$ \\
& SPF 5 & 0.5755 & 1450.653 & -0.3882 & $\hat{y}=-563.1876+0.44 x_{1}+0.556 x_{2}+0.199 x_{3}$ \\
\hline
\end{tabular}

$x_{1}$ temperature, $x_{2}$ relative humidity, $x_{3}$ light intensity, $y$ ozone and TVOCs concentration

Table 8 Dependence of temperature, humidity, light intensity on ozone and TVOCs concentrations

\begin{tabular}{lllrrl}
\hline Pollutant & Sampling location & $\begin{array}{l}\text { Multiple coefficient } \\
\text { of determination }\end{array}$ & SD & $t$ & Regression model \\
\hline Ozone & WOPF 1 & 0.9553 & 0.5845 & -0.5054 & $\hat{y}=-0.0295+0.714 x_{1}-0.42 x_{2}-0.73 x_{3}$ \\
& WOPF 2 & 0.2226 & 0.2127 & -0.1950 & $\hat{y}=-0.415+0.289 x_{1}+0.242 x_{2}+0.107 x_{3}$ \\
TVOCs & WOPF 1 & 0.9928 & 71.5376 & -7.13 & $\hat{y}=-510.0804+0.44 x_{1}+0.76 x_{2}+0.869 x_{3}$ \\
& WOPF 2 & 0.9887 & 228.1005 & 2.6819 & $\hat{y}=611.7334-0.55 x_{1}+0.557 x_{2}-0.29 x_{3}$ \\
\hline
\end{tabular}

$x_{1}$ temperature, $x_{2}$ relative humidity, $x_{3}$ light intensity, $y$ ozone and TVOCs concentration

\section{Flexographic printing}

In flexographic printing facilities, high values of multiple coefficients of determination (FPF 1-5, Table 9) confirmed a strong correlation between the observed phenomena.

Coefficients of determination in printing facilities FPF 5, FPF 2 and FPF 3 indicate a medium correlation between $t, \mathrm{RH}, \mathrm{LI}$ and the ozone concentration; Table 9. The coefficients of FPF1, FPF3, FPF4 and FPF5 indicate a medium correlation between $\mathrm{t}, \mathrm{RH}, \mathrm{LI}$ and TVOCs concentration; Table 9.

The standard errors of regression were large at all sampling locations (FPF 1-5, Table 9).

Values of $|t|$ higher than $t_{\text {critical }}$ occurred only at sampling location FPF 1, during the examination of dependence between $t, \mathrm{RH}, \mathrm{LI}$ and ozone concentration. For all other sampling locations, the values of parameter $|t|$ were less than $t_{\text {critical }}$, confirming a weak correlation between the observed parameters.
Figure 5 represents the spatial dependence of ozone concentrations on three independent variables-temperature, relative humidity and light intensity in FPF 1 . The $y$ values $>0.5$ (Fig. 5) show the highest dependence between ozone concentrations and microclimate parameters.

\section{Digital printing}

The highest values of multiple coefficients of determination were identified in all investigated digital printing facilities (DPF 1-5, Table 10). Based on the obtained results, it can be concluded that there is a strong correlation between the observed phenomena. The decrease in the coefficients of determination at sampling locations DPF 2 and DPF 4 contributed to a medium correlation between observed phenomena.

The values of the standard error of regression were large, especially at sampling locations DPF 5and DPF 2 
Table 9 Dependence of temperature, humidity, light intensity on ozone and TVOCs concentrations

\begin{tabular}{lllrll}
\hline Pollutant & Sampling location & $\begin{array}{l}\text { Multiple coefficient } \\
\text { of determination }\end{array}$ & SD & $t$ & Regression model \\
\hline Ozone & FPF 1 & 0.9867 & 0.1573 & 4.6683 & $\hat{y}=0.7342-1.1 x_{1}-0.71 x_{2}-0.48 x_{3}$ \\
& FPF 2 & 0.6702 & 0.0314 & 0.3026 & $\hat{y}=0.0095-0.21 x_{1}+0.339 x_{2}+0.241 x_{3}$ \\
& FPF 3 & 0.5789 & 2.7681 & -0.3657 & $\hat{y}=-1.0124+0.96 x_{1}+0.506 x_{2}-0.12 x_{3}$ \\
& FPF 4 & 2.7817 & 0.2275 & $\hat{y}=0.6329+0.135 x_{2}-0.92 x_{3}$ \\
& FPF 5 & 5.9765 & 1028.837 & 0.2861 & $\hat{y}=294.3512-1.1 x_{1}-0.42 x_{2}+1.04 x_{3}$ \\
TVOCs & FPF 1 & 0.7695 & 289.9424 & -1.4830 & $\hat{y}=-430.1236-0.77 x_{1}+0.657 x_{2}+1.11 x_{3}$ \\
& FPF 2 & 0.6285 & 434.1360 & 0.1504 & $\hat{y}=65.2914-0.57 x_{1}+0.157 x_{2}+0.689 x_{3}$ \\
& FPF 3 & 0.9309 & 3414.132 & 1.2772 & $\hat{y}=4360.6674-2.7 x_{1}-1.8 x_{2}+1.32 x_{3}$ \\
& FPF 4 & 0.7526 & 208.6538 & -0.0059 & $\hat{y}=-1.2248-0.69 x_{1}+0.657 x_{2}+0.756 x_{3}$ \\
\hline
\end{tabular}

$x_{1}$ temperature, $x_{2}$ relative humidity, $x_{3}$ light intensity, $y$ ozone and TVOCs concentration

Table 10 Dependence of temperature, humidity, light intensity on ozone and TVOCs concentrations

\begin{tabular}{llllll}
\hline Pollutant & Sampling location & $\begin{array}{l}\text { Multiple coefficient } \\
\text { of determination }\end{array}$ & SD & $t$ & Regression model \\
\hline Ozone & DPF 1 & 0.8432 & 0.4311 & -0.7106 & $\hat{y}=-0.3063+2.47 x_{1}+1.7 x_{2}+0.029 x_{3}$ \\
& DPF 2 & 0.7410 & 0.1957 & -1.448 & $\hat{y}=-0.2836+3.0 x_{1}+2.02 x_{2}-0.229 x_{3}$ \\
& DPF 3 & 0.9909 & 0.1032 & -6.091 & $\hat{y}=-0.6288+0.971 x_{1}+0.163 x_{2}+0.124 x_{3}$ \\
& DPF 4 & 0.9584 & 16.2214 & -3.657 & $\hat{y}=-59.3267+6.4 x_{1}+6.44 x_{2}-0.78 x_{3}$ \\
& DPF 5 & 20.2186 & -0.0621 & $\hat{y}=-1.2552+1.11 x_{1}+0.71 x_{2}-0.69 x_{3}$ \\
TVOCs & DPF 1 & 0.9722 & 282.5348 & -0.1515 & $\hat{y}=-42.8035+0.259 x_{1}+1.12 x_{2}-0.47 x_{3}$ \\
& DPF 2 & 0.9969 & 0.9529 & 0.6846 & $\hat{y}=0.6524-0.55 x_{1}+0.23 x_{2}-0.24 x_{3}$ \\
& DPF 3 & 0.9452 & 1.1316 & 0.9823 & $\hat{y}=1.1116-0.92 x_{1}-1.5 x_{2}+0.105 x_{3}$ \\
& DPF 4 & 0.8716 & 68.1736 & -3.08 & $\hat{y}=-209.964+10.4 x_{1}+9.08 x_{2}-2.4 x_{3}$ \\
\hline
\end{tabular}

$x_{1}$ temperature, $x_{2}$ relative humidity, $x_{3}$ light intensity, $y$ ozone and TVOCs concentration

(Table 10). Based on the obtained regression models, the prediction is less reliable.

Values of $|t|$ higher than $t_{\text {critical }}$ appeared at sampling locations DPF 3 and DPF 5 during the examination of dependence between $t, \mathrm{RH}, \mathrm{LI}$ and ozone concentration as well as at sampling location DPF 5 during the investigation of dependence between $t$, RH, LI and TVOCs concentration. For all other sampling locations, the obtained values of parameter $|t|$ were smaller than $t_{\text {critical }}$, so there is not enough evidence to confirm the correlation between the parameters.
Figure 6 represents the spatial dependence of TVOCs concentrations on three independent variables-temperature, relative humidity and light intensity in DPF 1 . The $y$ values $>140$ (Fig. 6) show the highest dependence between TVOCs concentrations and microclimate parameters.

\section{Industrial ecology of graphic industry}

Pollution prevention is achieved by reducing use of raw materials so as to reduce the amount of half-breeds who could enter the environment through recycling, some 
chemical treatment or disposal, which reduces the potential risks to the environment and human health. This is achieved by modifying equipment, changing production processes, reformulation or redesign of products or raw materials, and increases control storage and maintenance of such materials. Economic growth tends to increase the volume of pollutants. In the area of emissions into the atmosphere, improvements in technology are constantly competing with increased demand. Economic analysis of pollution control offers solutions for policies that address the specific problems of emissions, while the theory of industrial ecology offers an overview of the relationship activities that cause pollution and natural environment (Garcia-Serna et al. 2007; Gil et al. 2014).

We examined the possibility of using the tools of industrial ecology in order to change graphics technologies and graphic production with an explanation of ways of application of industrial ecology in the production process of the graphic industry in order to solve problems and develop strategies for the implementation of cleaner production. Cleaner production is a modern approach that provides the greatest contributions to the industry sector. This approach is part of the concept of sustainable development that takes into account that the limited capacity of the environment to accept a certain amount of pollutants so that no irreparable damage to the environment (Kiurski 2010). The most important aspect of industrial ecology is that there is no waste in a single production step because it is a total waste of resource to another manufacturing process in another industry. In this way the waste converts into a profit. All the principles that are at the lower level of industrial ecology form the basis of industrial ecology make it a success.

Graphics industry was in the area of production, graphic and raw materials, or as a printing operation, relatively low cost can significantly affect the environment responsible disposal of waste products (Kiurski 2010).

There are several ways to reduce VOC emissions from the printing industry. One or a combination of several of these strategies may result in the reduction of VOC emission reduction potential costs:

- Direct substitution: A procedure where identical chemical compounds derived from plants substitute petrochemical compounds,

- Indirect substitution: A procedure in which functionally similar, but chemically different substance obtained from plants substitute substance obtained from oil,

- Partial substitution: still be in use some of the VOC but in smaller amounts,

- The substitution process: VOC emissions can be reduced by adopting new methods and printing process; an example is the process of dry offset where there is no need for the use of wetting agents and where are using color-based plants, there are other benefits to the environment, which deal obtained by the use of dry offset (Martinović 2009).

Another way to reduce VOC printing is the process of digital printing. Digital printing has previously been most suitable for low-circulation duties, but is increasingly being applied.

\section{Conclusion}

The results of the quantitative identification of hazards are shown through the analysis of waste inks, the removal of $\mathrm{Zn}$ (II) ion from a waste printing developer, the preliminary monitoring of ambient air quality, as well as the multiple linear regression analysis applied on the obtained results of ambient air quality monitoring.

The analysis of waste inks confirmed the presence of heavy metal ions, including those of copper, cadmium, iron, silver, chromium, and zinc, in all ink samples. Only the concentrations of copper exceeded the maximum allowed concentration of $1 \mathrm{mg} / \mathrm{L}$, prescribed by Water Law of Serbia, which indicates that the copper concentration was up to 450 times higher than the allowable concentration.

The removal of $\mathrm{Zn}$ (II) ion from a waste printing developer is performed by using different low-cost adsorbents: activated carbon, clinoptilolite, a mixture of activated carbon and clinoptilolite, bentonite, fired clay and modified fired clay. The highest efficiency of all used adsorbents was achieved by modified clay materials, with $92.28 \%$ of $\mathrm{Zn}(\mathrm{II})$ ion removal.

The preliminary monitoring of ambient air quality indicated that increased TVOCs concentrations affect higher indoor ozone concentrations. The maximum average concentrations of ozone were above the permissible exposure limit of $0.1 \mathrm{ppm}$ in all investigated printing facilities, except in the web-fed offset printing facility. The reason for the increased TVOCs and ozone concentration is the widespread use of solvent-based inks and cleaning solutions.

The multiple linear regression analysis determined the quantitative correlation between microclimate parameters, ozone and TVOCs concentrations. The investigation of dependence between microclimate parameters and ozone concentration showed the highest multiple coefficients of determination at sampling locations PPF 3 (0.9558), SPF 2 (0.9906), FPF 1 (0.9867) and DPF 3 (0.9909), whereas strong correlation between TVOCs and microclimate parameters by value of coefficient 0.9928 was obtained at sampling location WOPF 1. 
The intensifying of printing processes, the usage of solvent-based inks and cleaning solutions and the changes in microclimate conditions in indoor printing environment are the main emission sources of total volatile organic compounds and ozone.

Based on the results and data classification collected under real conditions of the printing production, the introduction of adequate eco-friendly replacements for certain toxic substances must be suggested. In this manner, the physical and chemical characteristics of the materials will have a positive impact on the profitability and efficiency of technological processes, as well as on the quality of life and the working environment.

Acknowledgments The authors acknowledge the financial support of the Ministry of Education, Science and Technological Development of the Republic of Serbia (Project No. TR 34014).

\section{References}

Aeroqual Ltd (2014) http://www.aeroqual.com/product/series-200portable-ozone-monitor. Accessed 17 July 2015

Aina M, Matejka G, Mama D, Yao B, Moudachirou M (2009) Characterization of stabilized waste: evaluation of pollution risk. Int J Environ Sci Tech 6:159-165. doi:10.1007/BF03326070

Al-Salem S, Evangelisti S, Lettieri P (2014) Life cycle assessment of alternative technologies for municipal solid waste and plastic solid waste management in the Greater London area. Chem Eng J 244:391-402. doi:10.1016/j.cej.2014.01.066

An T, Huang Y, Li G, He Z, Chen J, Zhang C (2014) Pollution profiles and health risk assessment of VOCs emitted during e-waste dismantling processes associated with different dismantling methods. Environ Int 73:186-194. doi:10.1016/j.envint. 2014.07.019

Andrade L, Míguez C, Gomez M, Bugallo P (2012) Management strategy for hazardous waste from atomised SME: application to the printing industry. J Clean Prod 35:214-229. doi:10.1016/j. jclepro.2012.05.014

Bao C, Fang C (2013) Geographical and environmental perspectives for the sustainable development of renewable energy in urbanizing China. Renew Sust Energ Rev 27:464-474. doi:10.1016/j. rser.2013.07.008

Bernd Schwegmann GmbH \& Co (2015) Washing and cleaning solutions for offset printing. http://www.schwegmannnet.de/ PDF/Broschueren/Druck/EN/WashingAndCleaningSolutions_ Broschuere_EN.pdf. Accessed 15 June 2015

Bilen K, Ozyurt O, Bakrici K, Karsli S, Erdogan S, Yılmaz M et al (2008) Energy production, consumption, and environmental pollution for sustainable development: a case study in Turkey. Renew Sust Energ Rev 12:1529-1561. doi:10.1016/j.rser.2007. 03.003

Caselli M, Gennaro G, Saracino M, Tutino M (2009) Indoor contaminants from newspapers: VOCs emissions in newspaper stands. Environ Res 109:149-157. doi:10.1016/j.envres.2008.10. 011

Deblonde T, Cossu-Leguille C, Hartemann P (2011) Emerging pollutants in wastewater: a review of the literature. Int J Hyg Environ Heal 214:442-448. doi:10.1016/j.ijheh.2011.08.002

Dhada I, Nagar PK, Sharma M (2015) Photo-catalytic oxidation of individual and mixture of benzene, toluene and p-xylene. Int $\mathbf{J}$ Environ Sci Tech. doi:10.1007/s13762-015-0783-4
Dursun S, Kunt F, Taylan O (2015) Modelling sulphur dioxide levels of Konya city using artificial intelligent related to ozone, nitrogen dioxide and meteorological factors. Int J Environ Sci Tech. doi:10.1007/s13762-015-0821-2

E3 Systems Ltd (2015) Pad printing theory. http://www.e3systems.ca/ uploads/Pad_Printing_Theory.pdf. Accessed 15 July 2015

Environmental Protection Agency (EPA) (2015) Printing and publishing. http://cfpub.epa.gov/oarweb/mkb/indtype.cfm?Industry ID=7. Accessed 15 July 2015

Fotronic Corporation (2015) http://www.testequipmentdepot.com/ general/mini-airflow/air-flow-meter-dlaf8000.htm. Accessed 17 July 2015

Garcia-Serna J, Perez-Barrigon L, Cocero M (2007) New trends for design towards sustainability in chemical engineering: green engineering. Chem Eng J 133:7-30. doi:10.1016/j.cej.2007.02. 028

Gavrilescu M, Demnerová K, Aamand J, Agathos S, Fava F (2015) Emerging pollutants in the environment: present and future challenges in biomonitoring, ecological risks and ioremediation. New Biotechnol 32:147-156. doi:10.1016/j.nbt.2014.01.001

Gil R, Ruiz B, Lozano M, Martín M, Fuente E (2014) VOCs removal by adsorption onto activated carbons from biocollagenic wastes of vegetable tanning. Chem Eng J 245:80-88. doi:10.1016/j.cej. 2014.02.012

Greene K, Tonjes D (2014) Quantitative assessments of municipal waste management systems: using different indicators to compare and rank programs in New York State. Waste Manag 34:825-836. doi:10.1016/j.wasman.2013.12.020

Guo H, Lee S, Chan L, Li W (2004) Risk assessment of exposure to volatile organic compounds in different indoor environments. Environ Res 94:57-66. doi:10.1016/S0013-9351(03)00035-5

Hoenicke R, Oros D, Oram J, Taberski K (2007) Adapting an ambient monitoring program to the challenge of managing emerging pollutants in the San Francisco Estuary. Environ Res 105:132-144. doi:10.1016/j.envres.2007.01.005

Huang P, Shih L (2008) Effective environmental management through environmental knowledge management. Int $\mathrm{J}$ Environ Sci Tech 6:35-50. doi:10.1007/BF03326058

Ji C, D'Souz J, Batterman S (2008) Distributions of personal VOC exposures: a population-based analysis. Environ Int 34:922-931. doi:10.1016/j.envint.2008.02.002

Johnson J (2008) Aspects of flexographic print quality and relationship to some printing parameters. Dissertation, Karlstad University Studies, Faculty of Technology and Science Chemical Engineering, Karlstad, Sweden

Kamyshny A, Steinke J, Magdassi S (2011) Metal-based inkjet inks for printed electronics. Open Appl Phys J 4:19-36

Karanikas E, Nikolaidis E, Tsatsaroni E (2013) Preparation of novel ink-jet inks with antimicrobial and bacteriostatic properties to be used for digital printing of polyester and polyamide fibers. Prog Org Coat 76:1112-1118. doi:10.1016/j.porgcoat.2013.03. 008

Kiurski J (2010) Register of pollutants in printing industry of Novi Sad, 1st edn. Faculty of Technical Sciences, University of Novi Sad, Novi Sad (in Serbian)

Kiurski J, Vojinović-Miloradov M, Krstić J, Oros I, Adamović D, Kovačević I (2009) Chemical treatment of wastewater in printing industry. Paper presented at the 16th international symposium on analytical and environmental problems, Szeged pp 408-411

Kiurski J, Adamović D, Oros I, Krstić J, Adamović S, Vojinović Miloradov M et al (2011) Correlation between ozone and total VOCs in printing environment. J Chem Chem Eng 5:423-428

Kiurski J, Adamović S, Oros I, Krstić J, Vojinović Miloradov M (2012a) The removal efficiency of heavy metals from spent printing developer. Carpath J Earth Environ 7:5-16 
Kiurski J, Marić B, Adamović D, Mihailović A, Grujić S, Oros I et al (2012b) Register of hazardous materials in printing industry as a tool for sustainable development management. Renew Sust Energ Rev 16:660-667

Kiurski J, Marić B, Djaković V, Adamović S, Oros I, Krstić J (2012c) The impact factors of the environmental pollution and workers health in printing industry. In: Proceedings of world academy of science, engineering and technology, vol 6, pp 755-758

Kiurski J, Ranogajec J, Vučetić S, Zorić D, Adamović S, Oros I et al (2012d) Fired clay with polymer addition as printing developer purifier. Appl Clay Sci 65-66:48-52

Kiurski J, Aksentijević S, Nedović Lj, Oros I, Čomić L (2013a) The influence of printing microclimate parameters on isopropyl alcohol emission. Environ Eng Manag J (accepted)

Kiurski J, Kecić V, Oros I, Anđelić G, Đaković V (2013b) Pollutants emission during the printing on collagen casings for meat products, In: Proceedings of 8th international conference of the chemical societies of the south-east European countries (ICOSECS 8), p 249

Kiurski J, Marić B, Aksentijević S, Oros I, Kecić V, Kovačević I (2013c) Indoor air quality investigation from screen printing industry. Renew Sust Energ Rev 28:224-231. doi:10.1016/j.rser. 2013.07.039

Kiurski J, Ranogajec J, Oros I, Zorić D (2013d) Fired clay, an effective natural adsorbent for printing developer purifying. Fresen Environ Bull 22:3860-3864

Kommalapati RR, Liang Z, Huque Z (2015) Photochemical model simulations of air quality for Houston-Galveston-Brazoria area and analysis of ozone-NOx-hydrocarbon sensitivity. Int J Environ Sci Tech. doi:10.1007/s13762-015-0862-6

Kumagai S, Kurumatani N, Arimoto A, Ichihara G (2013) Cholangiocarcinoma among offset colour proof-printing workers exposed to 1,2-dichloropropane and/or dichloromethane. Occup Environ Med 70:508-510. doi:10.1136/oemed-2012-101246

Maji S, Bhaskarwar A (2003) Pollution-preventing anionic lithographic inks. J Hazard Mate B105:103-119. doi:10.1016/j. jhazmat.2003.07.007

Martinović I (2009) Emissions of isopropyl alcohol from the sheet-fed offset printing, 1st edn. Faculty of Technical Sciences, University of Novi Sad, Novi Sad (in Serbian)

Misra V, Pandey S (2005) Hazardous waste, impact on health and environment for development of better waste management strategies in future in India. Environ Int 31:417-431. doi:10. 1016/j.envint.2004.08.005

Mollah M, Schennach R, Patscheider J, Promreuk S, Cocke D (2000) Plasma chemistry as a tool for green chemistry, environmental analysis and waste management. J Hazard Mater B79:301-320. doi:10.1016/S0304-3894(00)00279-X

Musee N, Lorenzen L, Aldrich C (2008) New methodology for hazardous waste classification using fuzzy set theory Part I. Knowledge acquisition. J Hazard Mater 154:1040-1051. doi:10. 1016/j.hazmat.2007.11.011

Ning X, Lin M, Shen L, Zhang J, Wang J, Wang Y et al (2014) Composition profiles and risk assessment of polycyclic aromatic hydrocarbons (PAHs) in sludge from ten textile dyeing plants. Environ Res 132:112-118. doi:10.1016/j.envres.2014.03.041

Noonpui S, Thiravetyan P, Nakbanpote W, Netpradit S (2010) Color removal from water-based ink wastewater by bagasse fly ash, sawdust fly ash and activated carbon. Chem Eng J 162:503-508. doi:10.1016/j.cej.2010.05.051

Nwachukwu M, Feng H, Alinnor J (2010) Assessment of heavy metal pollution in soil and their implications within and around mechanic villages. Int J Environ Sci Tech 7:347-358. doi:10. 1007/BF03326144

Occupational Safety and Health Administration (OSHA) Limits for air contaminants, toxic and hazardous substances, 1910.1000 TABLE Z-1. http://www.osha.gov. Accessed 20 May 2015

Panwar NL, Kaushik SC, Kothari S (2011) Role of renewable energy sources in environmental protection: a review. Renew Sust Energ Rev 15:1513-1524. doi:10.1016/j.rser.2010.11.037

Photovac Inc. (2002) http://www.equipcoservices.com/pdf/manuals/ photovac_voyager.pdf. Accessed 17 July 2015

Printers' National Environmental Assistance Center (PNEAC) (1995) Screen printing. http://www.pneac.org/printprocesses/screen/. Accessed 16 July 2015

Su F, Mukherjee B, Batterman S (2013) Determinants of personal, indoor and outdoor VOC concentrations: an analysis of the RIOPA data. Environ Res 126:192-203. doi:10.1016/j.envres. 2013.08.005

Svendsen K, Rognes S (2010) Exposure to organic solvents in the offset printing industry in Norway. Ann Occup Hyg 44:119-124

Thomas R (2013) Practical guide to ICP MS. Marcel Dekker, New York

Venkanna R, Nikhil GN, Siva Rao T, Sinha PR, Swamy YV (2015) Environmental monitoring of surface ozone and other trace gases over different time scales: chemistry, transport and modeling. Int J Environ Sci Tech 12:1749-1758. doi:10.1007/s13762-0140537-8

Vojinović-Miloradov M, Kiurski J (2010) Emerging substances of concern in the graphical industry. Paper presented at the 5 . International symposium on graphic engineering and design, GRID, Novi Sad, Serbia, pp 191-200

Vukadinić S, Popović J (2004) Mathematical statistics. Faculty of Transport and Traffic Engineering, Belgrade (in Serbian)

Vuković N (2007) Statistical conclusion. Faculty of Organizational Sciences, Belgrade (in Serbian)

Wallis A, Graymore M, Richards A (2011) Significance of environment in the assessment of sustainable development: the case for south west Victoria. Ecol Econ 70:595-605. doi:10.1016/j. ecolecon.2010.11.010

Wang S, Sun H, Ang H, Tadé M (2013) Adsorptive remediation of environmental pollutants using novel graphene-based nanomaterials. Chem Eng J 226:336-347. doi:10.1016/j.cej.2013.04.070

Water Law of the Republic of Serbia, Official Gazette of the Republic of Serbia, 30/10,67/11, 48/12; 2010, 2011, 2012 (in Serbian)

Yigitcanlar T, Kamruzzaman M (2014) Investigating the interplay between transport, land use and the environment: a review of the literature. Int J Environ Sci Tech 11:2121-2132. doi:10.1007/ s13762-014-0691-Z

Yigitcanlar T, Teriman S (2015) Rethinking sustainable urban development: towards an integrated planning and development process. Int J Environ Sci Tech 12:341-352. doi:10.1007/ s13762-013-0491-x

Zaman A (2013) Identification of waste management development drivers and potential emerging waste treatment technologies. Int J Environ Sci Tech 10:455-464. doi:10.1007/s13762-013-0187-2

Zhang J, Li X, Shi X, Hua M, Zhou X, Wang X (2012) Synthesis of core-shell acrylic-polyurethane hybrid latex as binder of aqueous pigment inks for digital inkjet printing. Prog Nat Sci Mater Int 22:71-78. doi:10.1016/j.pnsc.2011.12.012

Žižić M, Lovrić M, Pavličić D (2006) The methods of statistical analysis. Faculty of Economics, Belgrade (in Serbian)

Zori M, Soleimani-Gorgani A (2012) Ink-jet printing of microemulsion $\mathrm{TiO}_{2}$ nano-particles ink on the surface of glass. J Eur Ceram Soc 32:4271-4277 